\title{
Зуболікарська освіта в Україні: історичні нариси
}

\begin{abstract}
Резюме. Наприкінці ХІХ століття в Україні засновано приватні зуболікарські школи в Києві, Одесі, Харкові та Катеринославі. У 1920 році з формуванням нової організаційної моделі надання стоматологічної допомоги на засадах соціальної медицини підвищується потреба у забезпеченні системи охорони здоров'я стоматологічними кадрами. Реформування зуболікарської освіти в Україні має свої відмінності: з формуванням вищої стоматологічної освіти на одонтофаках медичних інститутів зберігаються та суттєво реформуються зуболікарські школи, що готують зубних лікарів, спеціалістів із середньою професійною медичною освітою. У статті подано архівні матеріали щодо реформування зуболікарських шкіл і особливості підготовки зубних лікарів на початку ХХ століття.

Ключові слова: стоматологічна допомога населенню України; зуболікарські школи; вища стоматологічна освіта; підготовка спеціалістів; нормативно-правові й архівні документи
\end{abstract}

Наприкінці XIX сторіччя (1891р.) на теренах Російської імперії запроваджується державне регулювання в наданні зуболікарської допомоги, а саме наказом «Про реформування навчання зуболікувальному мистецтву» було узаконено зуболікувальні школи й офіційно затверджено звання зубного лікаря. 7 травня 1891 року було видано статут приватних зуболікувальних шкіл, який регулював їхню діяльність $[1,2,10]$.

Зуболікарську допомогу надавали зубні лікарі й дантисти - спеціалісти, які не мали загальномедичної освіти та не вважалися лікарями. Зубні лікарі навчалися в приватних зуболікарських школах протягом 2,5 року за затвердженими програмами та після навчання мали складати іспит на медичному факультеті університету. Дантисти навчалися за індивідуальною програмою в приватних зуболікувальних кабінетах із подальшим складанням іспиту комісії при університеті. Підготовка дантистів проводилась до 7 травня 1900 року, а потім готували лише зубних лікарів. Дантисти мали право лікувати тільки зуби, а зубні лікарі - ще й захворювання порожнини рота. Медичну допомогу при щелепно-лицевих травмах і пораненнях надавали лікарі з вищою освітою, що спеціалізувалися на зуболі- карській практиці, щелепно-лицевій хірургії, після закінчення медичного факультету університету й називалися лікарями-одонтологами. Підготовка одонтологів тривала на медичних факультетах протягом чотирьох років, потім вони відбували навчання в приватній зуболікарській школі [3, 9].

Зуболікарські школи мали право відкривати лише в містах, де були університети, а очолити школу могли лише лікарі-одонтологи з вищою освітою. Перші зуболікарські школи в Україні засновано наприкінці XIX сторіччя: в Одесі - Т.О. Тичинським (1893) та I.I. Марголіним (1896), а іспити зубні лікарі складали в Імператорському Новоросійському університеті. В 1898 році зуболікарські школи було відкрито в м. Києві лікарями Л. Головчинером, С. Лур'є, О. Плінером, а іспити зубні лікарі складали в Імператорському університеті Святого Володимира. Згодом відкрилися Київська зуболікарська школа Л.С. Бланка, Київська зуболікарська школа приватдоцента Університету Св. Володимира М.М. Жука. В найстарішому в Україні Імператорському Харківському університеті, що був заснований у 1803 році В.Н. Каразіним, приймали іспити у зубних лікарів Харківської зуболікарської школи. Першу зуболі-

(C) «Oral and General Health», 2021

(c) Видавець Заславський 0.Ю. / Publisher Zaslavsky 0.Yu., 2021

Для кореспонденції: Слободяник М.В., кандидат медичних наук, кафедра стоматології, Національний університет охорони здоров'я України імені П.Л. Шупика, вул. Дорогожицька, 9, м. Київ, 04112, Україна; е-mail: maryana.slobodyanik@gmail.com

For correspondence: M.V. Slobodyanik, PhD, Department of Dentistry, Shupyk National Healthcare University of Ukraine, Dorohozhytska st., 9, Kyiv, 04112, Ukraine; e-mail: maryana.slobodyanik@gmail.com Full list of authors information is available at the end of the article. 
карську школу в Харкові було відкрито 1898 р., а другу - 1 вересня 1900 р. Цього ж року в Катеринославі, після організації Вищого гірського училища, було дозволено зубному лікарю А.І. Шредеру та хірургу з вищою освітою Р.Ю. Веберу відкрити зуболікарську школу, в якій із 1902 р. викладав і написав свою першу працю «Стоматологічна фармакологія» Ю.М. Гофунг [3, 9, 10].

Події Жовтневої революції 1917 року суттєво змінили основи організації системи охорони здоров'я, та стоматології зокрема. Тяжкі наслідки Першої світової війни та громадянської війни, висока захворюваність населення України, зокрема на інфекційні хвороби, стимулювали керівництво України до запровадження нової організаційної моделі надання медичної та стоматологічної допомоги, побудованої на соціальних засадах [2].

До Жовтневої революції усі зуболікарські школи в Україні були приватні, офіційно завідували в них дипломовані лікарі-одонтологи з вищою освітою. Такі школи були організовані в університетських містах, а саме в Харкові, Києві, Одесі, Катеринославі. В урядових лікарських установах, у міських і земських лікарнях посад зубних лікарів не було. Зуболікарська допомога була цілком у руках приватних лікарів. Лише окремі дипломовані лікарі обирали своєю спеціальністю лікування зубів, щелеп. Відсутність зв’язку зуболікарських шкіл із вищими медичними школами дуже обмежувала загальну медичну підготовку зубних лікарів. Недостатність освіти усвідомлювали самі зубні лікарі, які на своїх з'їздах вирішували звертатися до уряду про відкриття державних зуболікарських інститутів, але їх клопотання не були задоволені. Наслідки такої неуваги до вивчення та лікування захворювань щелепно-лицевої ділянки особливо проявилися в часи Першої світової війни, коли велика кількість поранених із пошкодженнями щелеп і зубів, спотворенням обличчя не діставали раціональної допомоги через відсутність у хірургів досвіду в цій галузі. Необхідність у такій допомозі й зумовила виділення в хірургії галузі, що спеціалізувалася на лікуванні захворювань порожнини рота, щелеп і суміжних ділянок лиця та шиї, - стоматології (від грец. слів «рот» $\mathrm{i}$ «слово»), яка набула широкого розвитку вже в радянській медицині $[3,9,10]$.

Зуболікарська допомога надавалася зубними лікарями та дантистами зазвичай у великих містах. У сільській місцевості стоматологічна допомога здійснювалася фельдшерами та земськими лікарями й зводилася переважно до видалення зубів або розтину абсцесу. Стоматологічна допомога на той час надавалася в основному приватними зуболікарськими кабінетами та була доступна лише для забезпечених громадян, які могли оплатити лікування. Приватна форма організації зуболікарської допомоги не була спроможна вирішити численні медико-санітарні та соціальні проблеми й задовольнити потреби населення. Доступ до цього виду медичної допомоги був обмежений як високою ціною, так і малою кількіс- тю зуболікарських кабінетів і підготовлених спеціалістів [10].

Ситуація у стоматологічному житті потребувала термінової розбудови системи охорони здоров'я та зуболікарської допомоги населенню. Декретами Народного комісаріату охорони здоров'я Української Радянської Соціалістичної Республіки (НКО3 УРСР) із квітня 1920 року розпочинається розбудова державної соціальної медицини, спрямована на масове охоплення населення медичною допомогою. 3 метою ефективного та доступного для всіх громадян медичного обслуговування запроваджувалося державне регулювання системи охорони здоров'я, що забезпечувалось коштами держави [2].

\section{Реорганізація зуболікарської освіти}

У 1920 р. стоматологія стала окремою дисципліною медицини, в Україні відбувалося становлення державної системи зуболікувальної допомоги, здійснювались пошуки оптимальних шляхів організації обслуговування міського та сільського населення [3, 10].

Постанова про реформу зуболікарської освіти, що була прийнята 1 жовтня 1918 р. та підписана народним комісаром охорони здоров'я М.О. Семашко при погодженні з народним комісаром просвіти М.М. Покровським і керівником зуболікарської підсекції П.Г. Дауге, відкривала шлях до запровадження вищої стоматологічної освіти [6].

Із березня 1920 р. на факультетах медичних університетів розпочали відкриватися кафедри стоматології, відчиняли двері також профільні одонтологічні вищі медичні заклади: 1922 р. в Києві відкрився Одонтологічний інститут. Разом із тим у пункті 2 цієї Постанови говорилося про закриття зуболікарських шкіл та використання їх матеріально-технічних баз для створення нових одонтологічних факультетів [6].

Система охорони здоров'я, висока поширеність стоматологічних хвороб та їх ускладнень потребували значно більшої кількості спеціалістів, ніж було в Україні. Підвищення потреби в зуболікарській допомозі відбувалося на тлі кадрової кризи в галузі. В Україні точилася громадянська війна, і значну кількість зубних лікарів було мобілізовано. Перші випуски одонтологічних інститутів планувалися лише через чотири роки. Певна кількість зубних лікарів проходили навчання на одонтологічних факультетах і лише частково надавали стоматологічну допомогу. Всі ці чинники поглиблювали кадрову кризу в галузі, тож увага НКОЗ УРСР була спрямована на збереження зуболікарських шкіл в університетських містах та підготовку фахівців із спеціальною середньою професійною освітою - зубних лікарів [3].

Таким чином, в Україні запроваджується інший шлях кадрового забезпечення стоматологічної галузі, відмінний від Росії та інших союзних республік, а саме: розбудова одонтологічних факультетів 


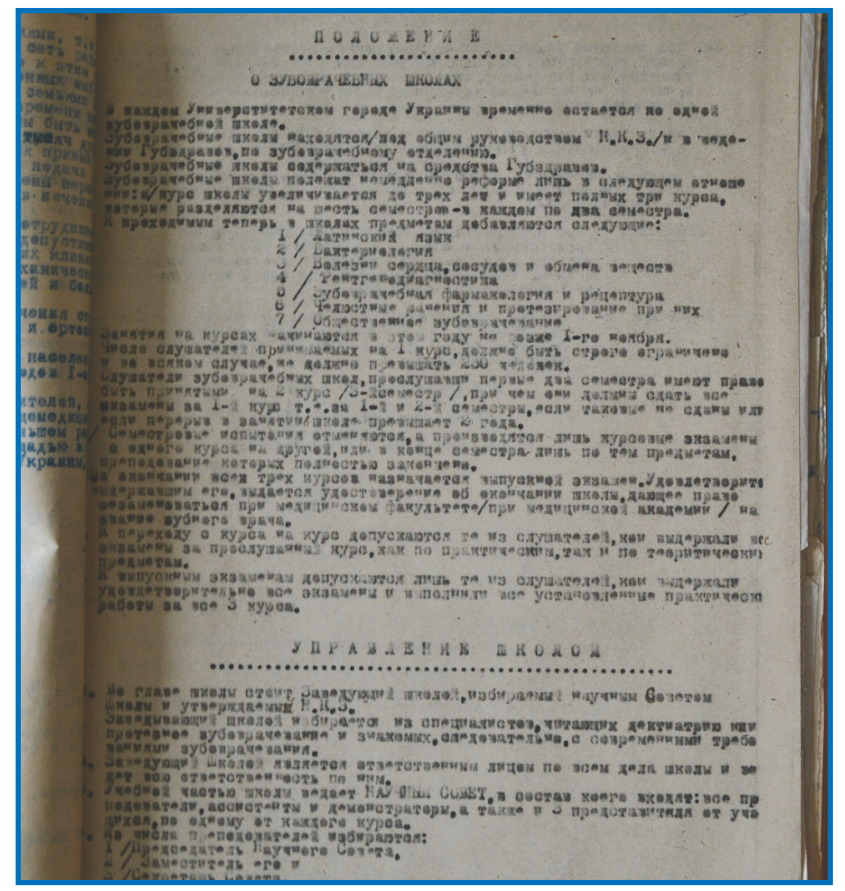

Рисунок 1. Положення про зуболікарські школи від 30 вересня 1920 року (перша сторінка)

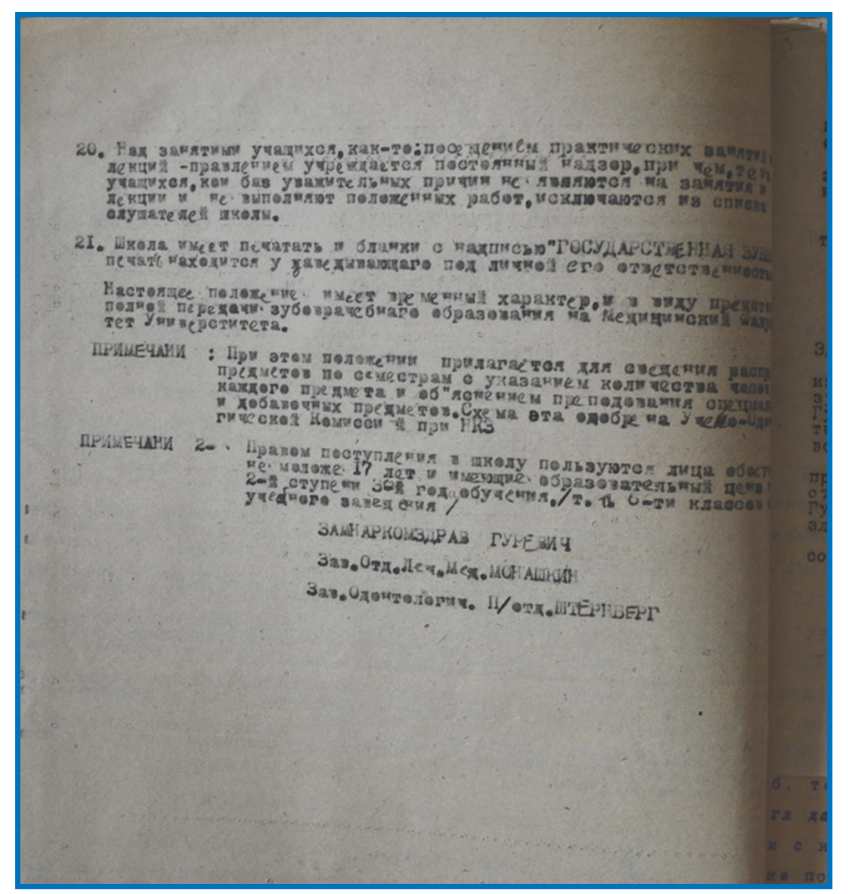

Рисунок 2. Положення про зуболікарські школи від 30 вересня 1920 року (друга сторінка)

му з навчання зубних лікарів та нові умови навчання й складання іспитів. Згідно з цим, у кожному університетському місті України тимчасово залишається по одній зуболікарській школі, що знаходиться під загальним керівництвом зуболікарського відділення НКО3 УРСР та утримується на кошти губернських відділів охорони здоров'я [5].

До прохідних предметів додаються загальномедичні та зуболікарські: латинська мова, бактеріологія, хвороби серця, судин і обміну речовин, рентгенодіагностика, зуболікарська фармакологія та рецептура, щелепні поранення та протезування при них, громадське зуболікування (рис. 1) [5].

Після закінчення всіх трьох курсів призначалися випускні іспити. При задовільній здачі іспитів видавалося посвідчення про закінчення школи, яке давало право екзаменуватися при медичних факультетах на звання «зубний лікар». До переходу до наступного курсу допускалися ті зі слухачів, які витримали всі іспити за курс і прослухали теоретичні предмети, а також пройшли практичні заняття. До випускних іспитів допускалися лише ті зі слухачів, які задовільно витримали всі іспити та виконали всі встановлені практичні роботи за три курси [5].

\section{Управління зуболікарською школою}

Згідно з Положенням про зуболікарські школи (рис. 1 та 2), очолював зуболікарську школу завідуючий школою, який обирався науковою радою школи та затверджувався Народним комісаріатом охорони здоров'я УРСР зі спеціалістів, які читали дентиатрію або протезне зуболікування й володіли сучасними методами зуболікування [5]. 


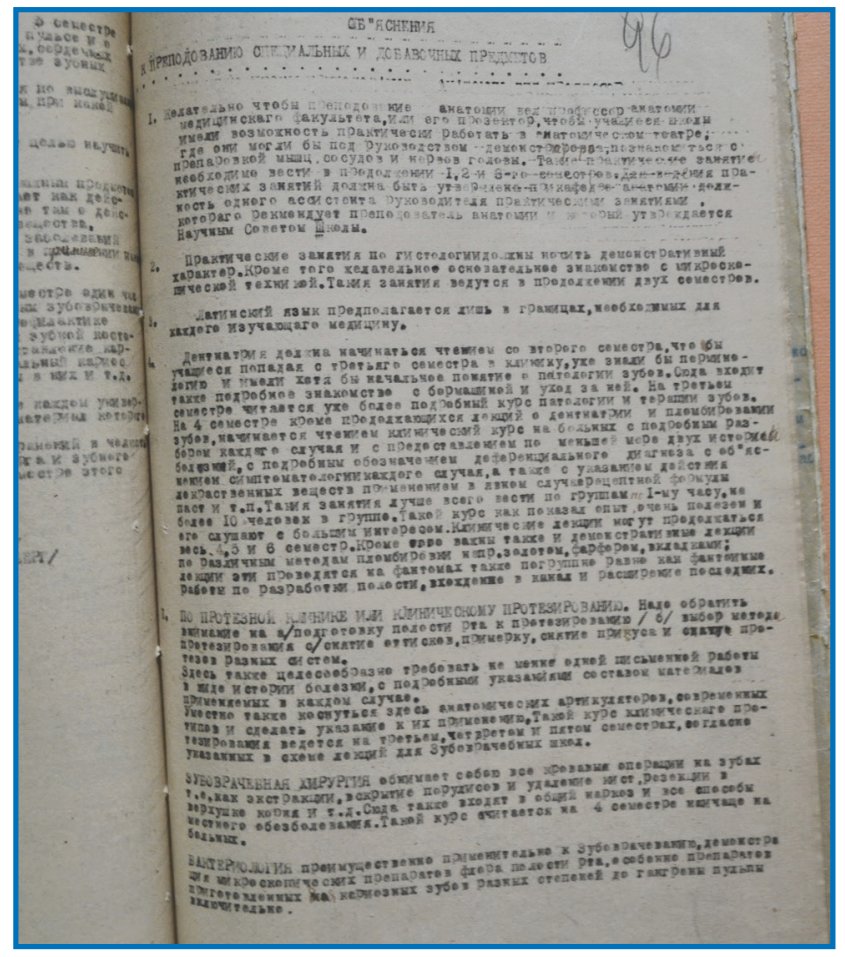

Рисунок 3. Роз'яснення наркома охорони здоров'я «До викладання додаткових та спеціальних предметів» (перша сторінка)

Навчальною частиною школи керувала наукова рада, до складу якої входили всі викладачі, асистенти та демонстратори, а також три представники від учнів - по одному від кожного курсу. 3 числа викладачів обиралися: голова наукової ради, заступник голови наукової ради та секретар ради. Наукова рада обирала зі свого боку двох членів, які разом із завідуючим школою являли собою правління школи [5].

Головою правління був завідуючий школою. Всі папери, які виходили з канцелярії школи, мали бути закріплені підписом завідуючого та діловодом школи. Над зайнятими учнями правлінням був заснований постійний нагляд, причому ті з учнів, які без поважних причин не з'являлися на заняття та лекції і не виконували покладених робіт, виключалися зі списків слухачів школи [5].

Для підтвердження державності та важливості зуболікарських шкіл кожна школа мала право друкувати бланки з надписом «Державна зубшкола», печатка знаходилася у завідуючого під особисту його відповідальність і контроль [5].

\section{Навчально-освітні програми зуболікарських шкіл}

До підготовки навчально-освітніх програм та викладання медичних і стоматологічних дисциплін у зуболікарських школах висувалися високі вимоги. Освітній процес у закладах освіти регулювався Народним комісаріатом охорони здоров'я УРСР у роз'ясненні наркома охорони здоров'я «До викладання додаткових та спеціальних предметів» (рис. 3 та 4) [4].

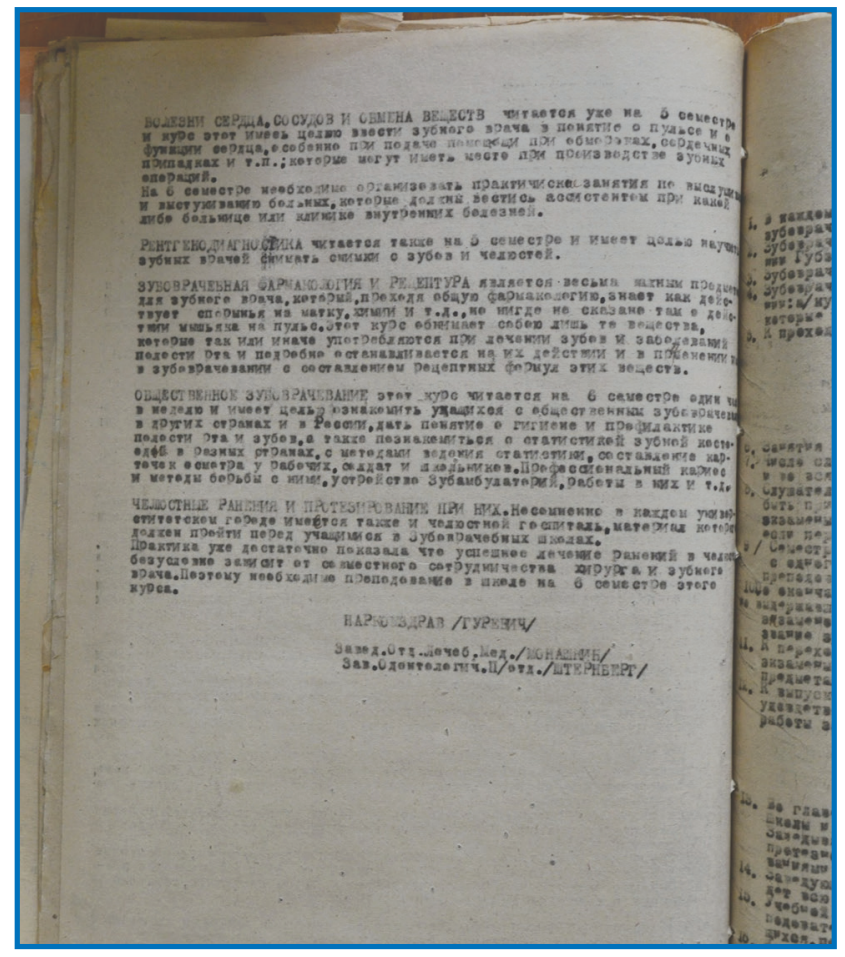

Рисунок 4. Роз'яснення наркома охорони здоров'я «До викладання додаткових та спеціальних предметів» (друга сторінка)

До загальних предметів у програму зуболікарських шкіл додались спеціалізовані дисципліни для всебічного розвитку зуболікарської освіти. Це були загальномедичні та спеціальні зуболікарські предмети. Із загальних медичних дисциплін у зуболікарських школах викладали: анатомію, гістологію, латинську мову, бактеріологію, хвороби серця, судин та обміну речовин, рентгенодіагностику тощо. До спеціальних зуболікарських дисциплін належали такі, як дентиатрія, протезна клініка та клінічне протезування, зуболікарська хірургія, зуболікарська фармакологія та рецептура, громадське зуболікування, щелепні поранення та протезування при них (рис. 3 та 4) [4].

При підготовці в зуболікарських школах значну увагу приділяли вивченню анатомії. 3 цією метою викладання анатомії мав проводити професор анатомії медичного факультету або його прозектор, щоб учні школи мали можливість практично працювати та під керівництвом демонстраторів ознайомлюватись з препаруванням м'язів, судин і нервів голови. Такі практичні заняття проводили протягом 1, 2 та 3-го семестрів. Ведення практичних занять було затверджено при кафедрі анатомії [4].

Практичні заняття з гістології мали демонстративний характер та являли собою знайомство з мікроскопічною технікою. Такі заняття проводилися протягом двох семестрів. Латинська мова викладалась у межах медицини з акцентом на вивчення медичної термінології [4].

Основи надання зуболікарської допомоги, а саме дентиатрії, майбутні зубні лікарі починали опано- 
вувати на другому семестрі навчання. Для зубних лікарів дентиатрія за роз'ясненням повинна розпочинатися читанням з другого семестру, щоб учні, потрапляючи з третього семестру в клініку, вже знали термінологію та мали загальне уявлення про патологію зубів. Сюди також входило докладне знайомство з бормашиною та догляд за нею. На 3-му семестрі викладається вже більш докладний курс патології та терапії зубів. На 4-му семестрі, крім лекцій з дентиатрії та пломбування зубів, розпочинається читання клінічного курсу на хворих із докладним розбором кожного випадку та наданням щонайменше двох історій хвороб із докладним позначенням диференціального діагнозу та поясненням симптоматології кожного випадку, а також із зазначенням дії лікарських речовин, застосуванням у певному випадку рецептної формули паст і т.п. [4].

3 метою глибокого опанування професії заняття мали проводитись по групах не більше ніж 10 чоловік у кожній. Клінічні лекції могли продовжуватися весь 4, 5 та 6-й семестри. Учні зуболікарських шкіл мали змогу відвідувати демонстративні лекції з різноманітних методів пломбування золотом, фарфором, вкладками. На заняттях курсанти слухали відповідні лекції, практичні заняття проводилися на фантомах, з розробкою каріозної порожнини та порожнини зуба, проходженням каналів та їх розширенням [4].

Крім дентиатрії, особливу увагу приділяли вивченню основ протезування зубів. На кафедрі зубопротезування займалися підготовкою порожнини рота до протезування, обирали методи протезування, знімали відтиски, здійснювали примірки, розробляли анатомічні артикулятори. Такий курс клінічного протезування встановлювався на 3, 4 та 5-му семестрах згідно з вказаним у схемі лекцій для зуболікарських шкіл. Також вимагалося не менше однієї письмової роботи у вигляді історії хвороби, з детальним зазначенням складу матеріалів, які використовуються в кожному випадку [4].

Зуболікарська хірургія обіймала екстракції зубів, розкриття абсцесів та видалення кіст, резекції верхівки кореня, загальний наркоз та всі методі місцевого знеболювання. Такий курс проводився на 4-му семестрі на пацієнтах (рис. 3) [4].

Викладання стоматологічних дисциплін проводилось із включенням інформації з основ мікробіології, для демонстрації використовувались мікроскопічні препарати флори із застосуванням бакматеріалів каріозних і гангренозних зубів [4].

3 метою посилення загальномедичних знань такі дисципліни, як хвороби серця, судин та обміну речовин, викладалися на 5-му семестрі, цей курс мав за мету ввести зубного лікаря в поняття внутрішніх хвороб з акцентом на маніпуляції, за яких пацієнт втрачає свідомість при зуболікарському втручанні. На 6-му семестрі організовувалися практичні заняття, що проводились асистентом у лікарні або клініці з відвідуванням і оглядом хворих (рис. 4) [4].

Рентгенодіагностика вводилась на 5-му семестрі та мала на меті навчити зубних лікарів робити знімки

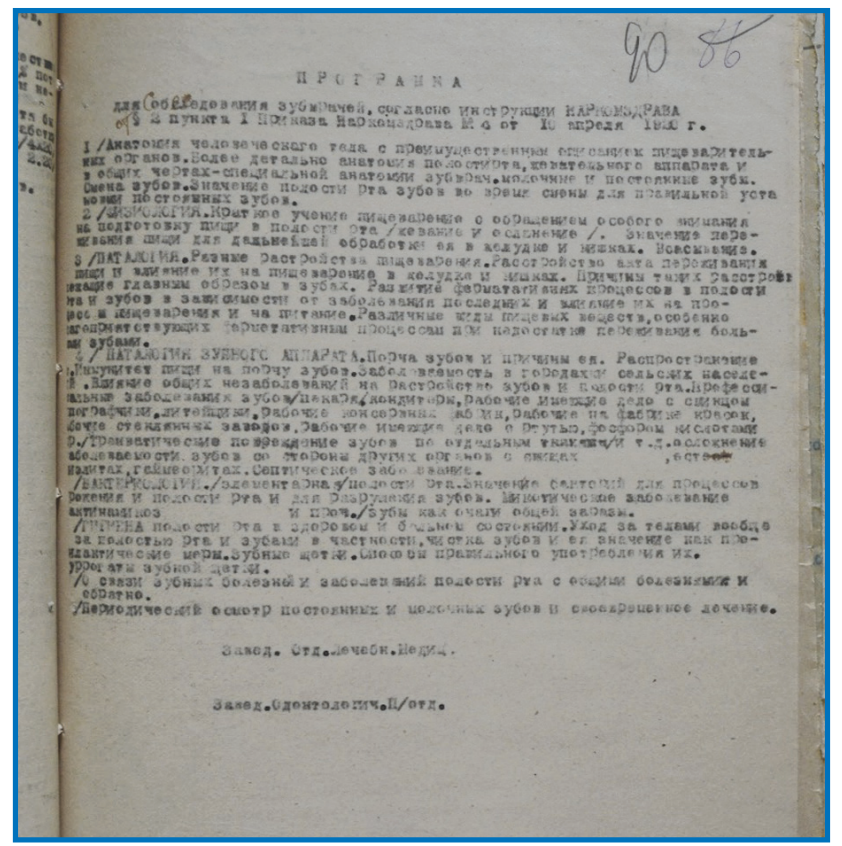

Рисунок 5. Програма співбесіди зубних лікарів згідно з Інструкцією Народного комісаріату охорони здоров'я § 2 пункту 1 наказу Народного комісаріату охорони здоров'я № 4 від 10 квітня 1920 року

зубів і щелеп. Дисципліна «зуболікарська фармакологія та рецептура» відрізнялась від «загальної фармакології» та мала навчити майбутніх зубних лікарів складати рецепти саме для надання зуболікарської допомоги, що використовуються лише для лікування зубів [4].

Важливим напрямом роботи в новій системі охорони здоров'я була профілактика захворювань шляхом введення загальної диспансеризації населення, вжиття оздоровчих і санітарних заходів [1]. Тому була започаткована така дисципліна, як «громадське зуболікування», що мала загальний ознайомчий характер, викладалася на 6-му семестрі один раз на тиждень і ставила на меті ознайомлення учнів із громадським зуболікуванням в інших країнах, а також давала поняття про гігієну й профілактику порожнини рота та зубів, знайомила зі статистикою в різних країнах світу, з методами ведення статистики, складання карточок огляду, вивчала професійний карієс, методи боротьби 3 ним, облаштування зубних амбулаторій і роботу в них (рис. 4) [4].

У післявоєнні часи в країні важливе місце посів такий предмет, як щелепні поранення та протезування при них. У кожному університетському місті завжди знаходився військовий госпіталь, де учні мали змогу ознайомлюватися з видами щелепних травм, поранень та проходити практичні заняття. Здійснювалося викладання щелепних поранень та протезування при них у зуболікарській школі на 6-му семестрі третього курсу [4].

Реформування зуболікарської освіти дало можливість у короткі строки вирішити кадрове питання 
стоматологічної допомоги населенню. Стоматологічна допомога надавалась у державних зуболікарських амбулаторіях, в амбулаторно-поліклінічних умовах. Налагоджувалася система надання амбулаторно-поліклінічної медичної допомоги за дільничним принципом, де лікарі-стоматологи працювали разом із терапевтами, хірургами, гінекологами й іншими медиками. На великих заводах, промислових підприємствах створювалися медико-санітарні амбулаторії (цехи), що надавали медичну та стоматологічну допомогу робітникам за місцем їх роботи. До складу бригад таких амбулаторій входили терапевти, хірурги, зубні лікарі. Таким чином реалізовувався новий принцип радянської медицини стоматологія стала невід'ємною частиною медичної допомоги [2].

\section{Критерії оціночної характеристики зубних Аікарів}

Відповідно до Програми співбесіди зубних лікарів, згідно з Інструкцією Народного комісаріату охорони здоров'я § 2 пункту 1 наказу Народного комісаріату охорони здоров’я № 4 від 10 квітня 1920 року, кожен фахівець мав досконало володіти знаннями щодо анатомії людського тіла з переважним описом травних органів і детальної анатомії порожнини рота, жувального апарату та анатомії молочних і постійних зубів, періодів зміни молочних зубів на постійні та значення здоров'я молочних зубів для правильного росту постійних (рис. 5) [8].

Велике значення мали знання з фізіології та патології травлення, при якій недостатнє функціонування жувального апарату негативно впливає на шлунково-кишковий тракт у цілому, що відіграє особливу роль при несприятливих ферментативних процесах. Тому важливими також були знання з патології зубного апарату. В цьому випадку необхідно володіти знаннями щодо псування зубів і причин їх руйнування, знати статистику захворюваності міського та сільського населення й особливості професійних захворювань зубів (стосувалося пекарів, кондитерів, робочих, які мають справу зі свинцем, ливарників, трудящих на заводах з виготовлення фарб, робочих скляних заводів, а також працівників, які мають справу зі ртуттю, фосфором, кислотами тощо) [8].

Майбутній фахівець повинен мати основні знання з бактеріології та гігієни порожнини рота та розуміти зв'язок зубних хвороб і захворювань порожнини рота із загальними хворобами, а також розуміти важливість періодичних оглядів постійних і молочних зубів, їх своєчасного лікування.

10 серпня 1920 року вийшла Постанова Народного комісаріату освіти та Народного комісаріату охорони здоров'я УРСР «Про перевірочні випробування для осіб, які закінчили зуболікарські школи», підписана наркомом освіти Г.Ф. Гриньком, наркомом охорони здоров'я М.Г. Гуревичем, завідуючим Левенсоном та завідуючим одонтологічним підвідділом Владиміровим. Згідно з цією

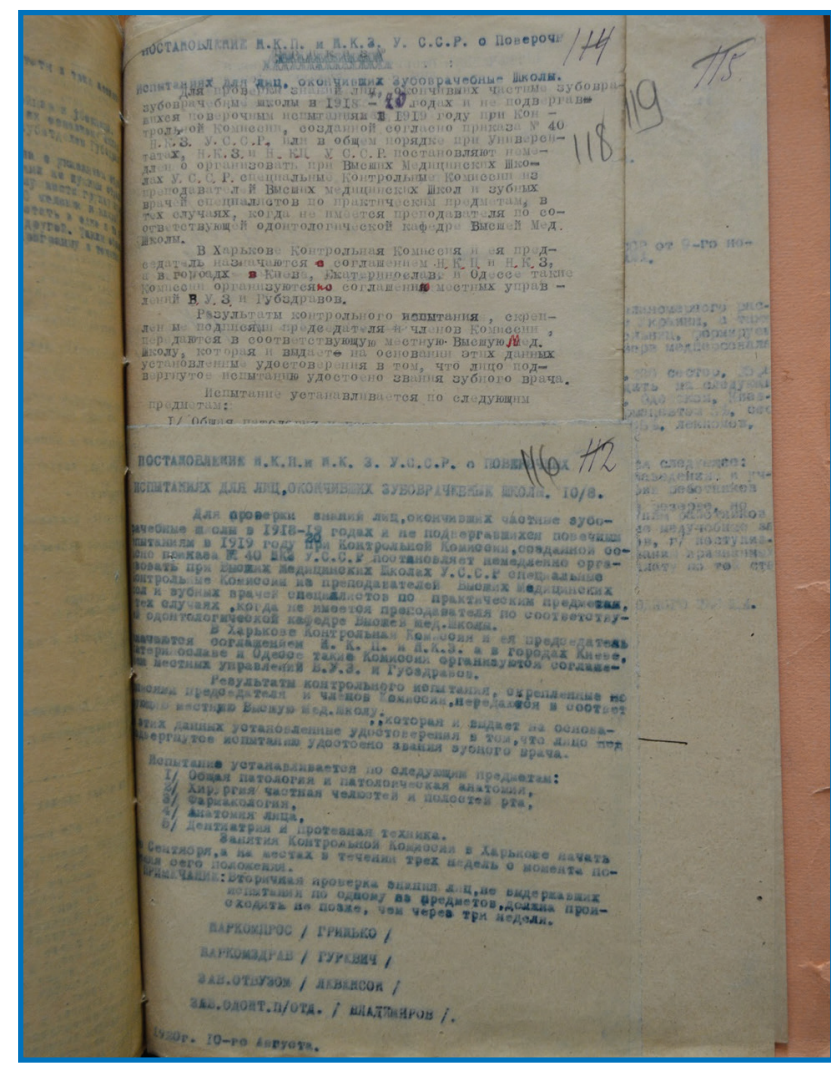

Рисунок 6. Постанова Народного комісаріату освіти та Народного комісаріату охорони здоров'я УРСР «Про перевірочні випробування для осіб, які закінчили зуболікарські школи» від 10.08.1920 p.

постановою, для перевірки знань зубних лікарів при вищих медичних школах УРСР організовувалися спеціальні контрольні комісії з викладачів вищих медичних шкіл та зубних лікарів - спеціалістів з практичних предметів. У Харкові контрольна комісія та її голова призначаються за згодою Народного комісаріату освіти та Народного комісаріату охорони здоров'я УРСР, а в містах Києві, Катеринославі та Одесі такі комісії організовуються за згодою місцевих управлінь при губернських відділах охорони здоров'я (рис. 6) [6]. Фактично в Україні на той час було 4 школи: в Києві, Одесі, Катеринославі та Харкові [6].

Результати контрольного випробування, закріплені підписами голови та членів комісії, передавалися у відповідну місцеву вищу медичну школу, яка на основі цих даних видавала посвідчення в тому, що особа піддавалась випробуванню та здобула звання зубного лікаря [7].

Випробування охоплювало кілька найважливіших предметів на перевірку теоретичних і практичних знань, а саме: загальна патологія та патологічна анатомія, щелепна хірургія та хірургія порожнини рота, фармакологія, анатомія обличчя та дентиатрія, протезна техніка. Якщо особа не проходила первинної перевірки знань, то не пізніше ніж через три тижні проводилася вторинна перевірка з даного випробування [7]. 
Таблиця 1. Лікувально-профілактичні заклади, що надавали стоматологічну допомогу в Україні, та кадровий потенціал галузі

\begin{tabular}{|l|c|c|c|c|c|c|c|}
\hline & 1927* & 1928* & 1933** & 1936* & 1937* & 1939* & 1940* \\
\hline $\begin{array}{l}\text { Заклади, що мають } \\
\text { зуболікарські відділення }\end{array}$ & 23 & 31 & $\begin{array}{c}1346 \\
(797 \text { у містах, } \\
549 \text { у селах })\end{array}$ & 1371 & 1467 & 1729 & 2229 \\
\hline $\begin{array}{l}\text { Кількість лікарів-стома- } \\
\text { тологів (уся група) }\end{array}$ & & & 1178 & 1535 & 1604 & 2247 & 2702 \\
\hline Кількість зубних лікарів & & & 1207 & 1068 & 853 & 1090 & 1644 \\
\hline
\end{tabular}

Примітки: * - за даними бюро медико-санітарної статистики Народного комісаріату охорони здоров'я УРСР, форма 90. Статистичні дані надано ДУ “Центр медичної статистики МОЗ України»; ** - за даними I пленуму Стоматологічної ради Народного комісаріату охорони здоров'я УРСР, 15-18 травня 1937 року, м. Одеса.

У 1920 р. стоматологія увійшла в окрему дисципліну, відбувалося становлення державної системи одонтологічної допомоги та пошуки оптимальних шляхів організації обслуговування міського та сільського населення. 3 березня 1920 р. на факультетах медичних університетів почали відкриватися кафедри стоматології, відчиняли двері також профільні одонтологічні вищі медичні заклади: 1922 р. у Києві відкрився Одонтологічний інститут, 1928 р. в Одесі - Науково-дослідницький інститут стоматології та ін. Також було запропоновано нову систему оцінки праці зубного лікаря, а саме: одиниця праці (20 хвилин для лікування одного каріозного зуба), ідея створення централізованої та безкоштовної системи охорони здоров'я, що була покладена в основу державної політики та реалізована на практиці $[9,10]$.

Завдяки реформуванню стоматологічної галузі у $\mathrm{XX}$ ст. і соціально-стоматологічної допомоги на засадах державного фінансування та удосконалення стоматологічної освіти в Україні відбувся приріст кадрового потенціалу стоматологічної галузі та лікувально-профілактичних закладів, що надавали стоматологічну допомогу населенню (табл. 1).

\section{ВИсновКИ}

Отже, в Україні запроваджується інший шлях кадрового забезпечення стоматологічної галузі, відмінний від Росії та інших союзних республік, а саме: розбудова одонтологічних факультетів (одонтофаки) та реорганізація (замість закриття) зуболікарських шкіл. Такий шлях розвитку стоматологічної освіти в Україні сприяв швидкому зростанню кадрового потенціалу галузі. В подальшому фахівці, які отримали стоматологічну освіту в Україні, за державним розподілом направлялися для надання зуболікарської допомоги та розбудови стоматологічної галузі у найвіддаленіші куточки Радянського Союзу.

Конфлікт інтересів. Автори заявляють про відсутність конфлікту інтересів та власної фінансової зацікавленості при підготовці даної статті.

\section{Список Аітератури}

1. Верхратський С.A. Історія медицини. 3-тє видання. Київ: Вища школа. Головне видавництво, 1983. С. 243; 351-352.

2. Мазур І.П. Історичні аспекти організації стоматологічної служби в Україні. Медична газета «Здоров'я України 21 сторіччя». 2019. № 21(466). С. 36-37.

3. Мазур І.П. Стоматологічна освіта - рушійна сила в розвитку стоматологічної галузі. Медична газета «Здоров'я України 21 сторіччя». 2019. № 17(462). С. 30-31. https://health-иa. com/article/44043-stomatologchna-osvta--rushjna-sila-rozvitkustomatologchno-galuz

4. Объяснение к преподаванию специальных и добавочных предметов. ЦДАВО України. Ф. 342. Оп. 2. Спр. 164. Накази, інструкції і обіжники одонтологічного підвідділу. Оригінал. Машинопис.

5. Положение «О зубоврачебных школах». ЦДАВО України. Ф. 342. Оп. 2, Спр. 140. Реформа зубоврачебного образования. НКОЗ 30.09.1920 р. Арк. 29-30. Оригінал. Машинопис.

6. Постановление «О реформе зубоврачебного образования». ЦДАВО Украӥни. Ф. 342. Оп. 2. Спр. 140. «Реформа зубоврачебного образования». Арк. 2. Копія. Машинопис.

7. Постановление НКП и НКЗ УССР о поверочных испытаниях для лии, окончивших зубоврачебные школы. ЦДАВО України. Ф. 342. On. 2. Спр. 164. Накази, інструкиї̈ і обіжники одонтологічного підвідділу. НКОЗ 10.08.1920 р. Арк. 118. Оригінал. Машинопис.

8. Программа для собеседования зубных врачей согласно инструкции Наркомздрава § 2 пункта 1 Приказа Наркомздрава № 4 om 10.04.1920 г. ЦДАВО України. Ф. 342. Оп. 2. Спр. 164. Накази, інструкції і обіжнники одонтологічного підвідділу. Арк. 90. Оригінал. Машинопис.

9. Стоматологія Украӥни. Історичні нариси. За ред. І.П. Мазур, О.В. Павленка, І.Л. Скрипник. Харків: СІМ, 2017. $192 c$.

10. Украӥнська наукова стоматологічна школа: історичні нариси. За ред. І.П. Мазур, О.В. Павленка, І.Л. Скрипник. Кропивницький: Поліум, 2020. 224 c. https://library.gov.ua/ukrayinskanaukova-stomatologichna-shkola/

Отримано/Received 01.12.2021

Рецензовано/Revised 15.12.2021 Прийнято до друку/Accepted 22.12.2021 


\section{Information about authors}

Vira Shymilina, Chair of the NGO "Dentists of Ukraine", dentist in Khmelnytsky Regional Dental Clinic, Khmelnytsky, Ukraine e-mail: veravita79@gmail.com; zubni.likarigo@gmail.com; phone $+380673115008$

Svitlana Khlebas, PhD, Shupyk National University of Public Health of Ukraine, Kyiv, Ukraine; e-mail: khlyebassv@ukr.net; https://orcid.org/0000-0002-3122-7131

Marianna Slobodyanik, Shupyk National University Healthcare of Health of Ukraine, Kyiv, Ukraine; e-mail: maryana.slobodyanik@gmail.com

Conflicts of interests. Authors declare the absence of any conflicts of interests and own financial interest that might be construed to influence the results or interpretation of their manuscript.

V.V. Shymilina1, S.V. Khlebas², M.V. Slobodyanik²

${ }^{1}$ Chair of the NGO "Dentists of Ukraine", MNPE "Khmelnytskyi Regional Dental Polyclinic", Khmelnytskyi, Ukraine

${ }^{2}$ Shupyk National Healthcare University of Ukraine, Kyiv, Ukraine

\section{Dental education in Ukraine: historical essays}

Abstract. At the end of the $19^{\text {th }}$ century, private dental schools were established in Ukraine in Kyiv, Odesa, Kharkiv, and Katerynoslav. In 1920, with the formation of a new organizational model for the provision of dental care on the basis of social medicine, the need to provide the health care system with dental staff increased. The reform of dental education in Ukraine has its differences: with the formation of higher dental education in the dental faculties of medical institutes, dental schools that train dentists, specialists with secondary professional medical education are preserved and significantly reformed. The article presents archival materials on the reform of dental schools and the peculiarities of the training of dentists in the early $20^{\text {th }}$ century.

Keywords: dental care for the population of Ukraine; dental schools; higher dental education; training of specialists; normativelegal and archival documents 